This is a pre-print version of an article that has been published in Poetics. The published version can be downloaded from:

http://www.sciencedirect.com/science/article/pii/S0304422X15000388

Please cite this article as:

Van der Hoeven, A. \& Brandellero, A. (2015). Places of popular music heritage: The local framing of a global cultural form in Dutch museums and archives. Poetics, 51, 37-53. doi: 10.1016/j.poetic.2015.05.001

\title{
Places of popular music heritage: the local framing of a global cultural form in Dutch museums and archives
}

\author{
Arno van der Hoeven* \\ Department of Media and Communication, Erasmus University Rotterdam \\ Amanda Brandellero \\ Department of Sociology, University of Amsterdam
}

\begin{abstract}
Through the prism of popular music, this article examines how the preservation and display of this global cultural form positions itself at the nexus of the local and the global, and in so doing mediates attachment to place. Springing from the increasing cultural legitimacy of popular music and the growing participation of fans and local communities in heritage practices, Dutch private and public heritage initiatives are analyzed to explore how the local histories and lived experiences of popular music reverberate in the framework of wider global cultural developments. The results of this study indicate that museums and archives give places meaning through three interrelated processes. They present local sociocultural histories, foster a sense of belonging and cultural pride, and seek to document the artistic
\end{abstract}

\footnotetext{
* Corresponding author: Erasmus University Rotterdam, ESHCC / Dept. of Media and Communication, P.O. Box 1738, NL-3000 DR Rotterdam, the Netherlands; Email address: vanderhoeven@eshcc.eur.nl
} 
legacy of places. Furthermore, it is found that despite the strong transnational dimension of popular music, the studied heritage practices strongly resonate with local and national cultural identities, as narratives of popular music and heritage are mediated by locally situated cultural gatekeepers. These findings are based on in-depth interviews conducted with archivists, collectors and curators from the Netherlands.

Keywords: popular music; cultural heritage; archives; museums; place; local identity.

\section{Introduction}

This article sheds light on the connections between popular music heritage and local and national cultural identity construction. Traditional notions of heritage as the exclusive domain of high art and tangible objects are progressively replaced with new conceptions that include contemporary popular culture (Moore, 1997). This follows from the blurring boundaries between high art and popular culture and the ensuing artistic legitimacy of cultural forms such as music and film (Bennett, 2009; Schmutz et al., 2010). Moreover, in recent decades, initiatives seeking to democratize heritage practices, such as community archives and the social history movement, have ensured a growing attention to 'history from below' (Flinn, 2007; Moore, 1997). Consequently, a burgeoning number of both private and public heritage practices engage with the contributions of popular music to the cultural landscape and everyday life of communities. Among these, exhibitions and archives typically frame popular music's past from a local perspective, focusing on the music histories and identities of specific places (Brandellero and Janssen, 2014; Cohen, 2013). Yet globalization calls into question what is local, by pointing to contested processes of identity building (Morley, 2001) and of representation of diversity by heritage institutions (Khabra, 2014; Van den Bosch, 2007).

Our focus on popular music as heritage offers a unique vantage point to explore these processes. As local popular music traditions are combined with foreign genres, the global and the local continuously intersect (Kong, 1997). Responses to this have varied, from the indigenization of global cultural styles (Regev, 2007) to the reassertion of place-bound identities in light of a perceived threat by globalization to local cultural uniqueness (Achterberg et al., 2011). More specifically, Dutch post-war popular music and the wider cultural landscape have proven to be open to influences from other countries (Janssen et al., 
2008; Schuyt and Taverne, 2004). We analyze therefore how locally based institutions negotiate their relevance in relation to the preservation of a global cultural form.

This article examines how museum and archives as heritage gatekeepers represent these connections between the local and the global and the ways in which they legitimize their heritage practices. In so doing, we address the following research question: How do museums and archives engaging in popular music heritage practices give form to understandings of place and local cultural identity? To answer this research question, this study draws upon interviews with curators, archivists and collectors. Heritage research to date has tended to focus on heritage practices solely from an institutional perspective (Smith, 2006). Therefore, this study examines both established heritage organizations and initiatives from the bottom-up. As amateur and professional curators and archivists in the Dutch field of popular music heritage often collaborate, this provides an apposite vantage point to explore the ways in which, independently and collectively, museums and archives give place meaning through their popular music heritage practices.

The article is divided into four parts. In the first part, extant literature on heritage institutions and the changing relations between heritage, identity and place are introduced. It then moves on to the methodology and a discussion of the different archives and exhibitions we examined. Next, we discuss the ways in which places are remembered through the popular music heritage practices of museums and archives. Finally, we analyze how museum curators and archivists negotiate the local-global nexus in practices of popular music heritage.

\section{The changing practices and institutions of heritage}

Heritage is the process through which the history of people and places is used to shape particular place-identities (Ashworth, 1994). Back in 1999, Stuart Hall remarked that the term heritage had "slipped so innocently into everyday speech", deflecting from its contested role in providing structures and "analytic frameworks which classify, place, compare and evaluate culture" (1999, p. 3 and 8). Heritage functions on a structural and cognitive level. On the former, it operates through a complex set of institutions and practices dedicated to the preservation and conservation of artefacts and 'things of value'. On the latter level, it participates in the active production of collective representations of the past by building on dominant and essentialised meanings of identities and narratives of place and projecting them onto what is preserved (Hall, 1999: 3-4; Graham et al., 2000). Heritage institutions render 
identity concrete through the preservation of "the store of knowledge from which a group derives an awareness of its unity and peculiarity" (Assman and Czaplicka, 1995, p. 130). The perceived innocence alluded to by Hall is derived from the naturalized and assumed connections between identity and place which heritage, as a discursive practice and a shared cultural meaning making process, weaves over time (Schwartz and Cook, 2002; Smith, 2006). However, the structures and cognitive lenses heritage offers have become more dissonant, as a result of challenges to their capacity to present a consensual and authoritative version of the past and identity attachments (Smith 2006; Weil, 1997).

On the structural level, museum and archives provide the institutional backbone of heritage as key sites of preservation, yet their form and mission have changed greatly through time. Museums were set up with an educating mission, elevating the broader public through a celebration of the deeds and tastes of the elites (Weil, 1997), actively participating in the formation of national identity and the spread of citizenship values (Bennett, 1995), as well as the production of memory (Featherstone, 2006; Newman and McLean, 2006). Similarly, in the XIX century, archives partook in processes of nation building, evolving from the sites where official records and documents on population and territories were stored to "the repository of the national history and national memory" (Featherstone, 2006, p. 592).

Historical evidence and documentation act by providing the buttresses through which identity is constructed, and the instruments through which archivists and curators validate its authority (Kaplan, 2000). Through their classification and display efforts of such evidence and documentation, these heritage institutions create meaning and provide a system of representation (Lidchi, 1997). Similarly, through exhibitions, museums put forward narratives of time and space (Newman and McLean, 2006, p. 57), engendering changes to the valuation and understanding of places (Moore and Pell, 2010). From this perspective, heritage institutions are cultural tools which help remember and define one's sense of social and geographical place (Wertsch, 2002), while offering the potential to objectify identity (Anico \& Peralta, 2009, p. 2). Museums and archives can thus be seen as locations where narratives about identities are articulated and displayed, but also 'discursive sites' where these identities are produced and consumed (McLean and Cooke, 2000, p. 149-157). 


\subsection{Challenges to museum and archives as heritage gatekeepers}

In recent decades, the structural and discursive repertoire of heritage has broadened, as a result of a number of challenges to the gatekeeping role museum and archives play. The first was one of inclusion, deriving from the "radical awareness of marginalized groups of the symbolic power involved in the activity of representation" (Hall, 1999, p. 7) which translated into growing demands for recognition of identity claims of diverse societal groups (see Fraser, 2001; Smith, 2010).

The second challenge is one of participation: heritage as a discursive practice has also evolved from a primarily top-down process of knowledge creation and diffusion to one where the public is increasingly on a par (Weil, 1997; Merriman, 1991). The notion that heritage professionals act as "interpretative communities that construe and construct the knowledge of their special fields" (Perin, 1992, p. 187-8), or indeed mobilize their status as experts to 'police' heritage (see Waterton and Smith, 2010) suggests a wider understanding of their role as enablers and facilitators of heritage (Emerick, 2009). Instances of collaboration between mainstream heritage institutions and the archival activities of marginalized groups testify to new forms and contexts of community engagement and resulting innovative approaches to custody, collecting and curation which thrive on valorizing alternative sources of expertise (Stevens et al., 2010; Waterton and Smith, 2010). Greater awareness and reflexivity on the power relations embodied in existing practices (Smith, 2010; Weil, 1997) has resulted in the enhanced democratization in museal and archival activities and proliferation of approaches, as exemplified by the rise of the social history museum and community archives by way of example (Crane, 1997; Moore, 1997; Hall, 2001; Featherstone, 2006; Flinn, 2007).

Community archives are the "grassroots activities of documenting, recording and exploring community heritage in which community participation, control and ownership of the project is essential" (Flinn, 2007, p. 153). The impetus behind the constitution of community archives is generally understood as rising from an enthusiasm to document a group's history “on their own terms" (Flinn et al., 2009, p. 73, italics in original), while addressing the lack of representation and visibility of the community concerned within mainstream institutional frameworks (Hall 2001). Therefore, community archives and community histories diversify the remembered voices, while enhancing the spectrum of what is kept (Flinn et al., 2009, p. 83). In describing how "a multiplicity of voices now engage in debates around definitions of history, culture and heritage that previously were confined to 
the realm of intellectuals and experts", Bennett (2009, p. 482) employs the term Do-ItYourself (DIY) preservationism. Focusing on the field of popular music, he highlights the burgeoning of bottom-up, amateur-based initiatives in the preservation of the aural heritage of places since the Second World War. This point brings us to a fundamental iterative involvement of users and audiences of both archives and museums, as they become increasingly participatory heritage environments (see Moore and Pell, 2010).

Thirdly, heritage practices have been challenged on grounds of their tendency to galvanize around place-based identities, an inheritance of its early nation-state building function and later of its commercial and tourism potential in the context of spatial planning and branding (Ashworth 1994). The relationship between heritage and place is almost 'tautological', as the former is the product and the determinant of the other (Ibid.), insofar as by "connecting stories of past experiences to present localities, public histories give places meaning" (Moore and Pell, 2010, p. 260), while these meanings become the key features of place differentiation. Yet the extent to which geography at which heritage activity takes place corresponds to an 'identity level' (Howard, 2003, p. 147) can be questioned. Traditional conceptions of heritage as the expression of identities fixed in a given place (Ashworth, 1994) are challenged by theories which argue that contemporary society is characterized by mobility and therefore identities are less embedded in bounded localities (Appadurai, 1990). Global migration patterns transform the spaces of belonging and identity (Morley, 2001), while cultural globalization and the exchanges of cultural goods, people and ideas calls for an understanding of culture as linked to ever more transnational fields of production and consumption (Crane, 2002), challenging spatially-bounded notions of cultural heritage. Moreover, the purpose and remembering also come into play: Liverpool's European Capital of Culture celebrations and their emphasis on the Beatles and White rock music heritage served to broaden the international appeal and audience of the events, yet they alienated local willing to give voice to the diverse music heritage of the city (Cohen, 2013). The example points to a simultaneous "disembedding" of identity from geographical localities (Ashworth et al., 2007) as it acquires meaning transnationally, while pointing to a process of 'reterritorialization' (Morley, 2001, p. 427) as the uniqueness of the Liverpool Sound is reappropriated and celebrated (Cohen 2013).

These processes call on heritage institutions to think about their value and meaning making activities in a relational way, particularly when addressing their audiences' attachment to localities (Hoebink, 2011). The emergence of social media, such as blogs and 
video-sharing websites, facilitates new possibilities for audience participation (Baym and Burnett, 2009; Cohen, 2013). On these so-called web 2.0 platforms, ranging from individual initiatives to community archives (Flinn et al., 2009), visitors are invited to upload memories or annotate archival material (Cohen, 2013; Snoek et al., 2010). By digitizing documents such as photos, audio tapes or videos it becomes easier to explore local content and share it with others. Meanwhile, grassroots preservation activities, often happening outside established heritage institutions, offer the possibility of presenting 'hidden' or alternative histories of particular places (Bennett, 2009). Technological developments and the wide availability of digital media resources have greatly facilitated online heritage practices (Flinn, 2007), overcoming issues of geographical proximity and tangibility of material. In exploring the transnational online 'virtual scenes' preserving the music heritage of progressive rock from Canterbury in the United Kingdom, Bennett $(2002,2009)$ addressed the symbolic and lifestyle bonds which unite audiences beyond spatial proximity or personal experience of a place. Digital communication methods become an instrument and an alternative 'place' to construct and share their understanding of this sonic history.

In view of the changing positioning of archives and museums in relation to their audiences, this article examines how understandings of place and of local cultural identities arise through the framing of popular music as cultural heritage. In doing so, it sets itself in the context of the recognized increasing cultural legitimacy of popular music in its relation to heritage practices and institutions (Brandellero and Janssen, 2014; Roberts and Cohen, 2014; Leonard, 2010). Through the prism of popular music, it addresses how the preservation and display of this cultural form mediates attachment to place and reflects the global nature of music as a cultural product, as local histories and lived experiences of popular music reverberate in the framework of wider global developments. We therefore ask how museum and archives engaging in the field of popular music heritage give form to understandings of place and local cultural identity.

\section{Methodology}

The research for this article has been conducted in the context of the project 'Popular Music Heritage, Cultural Memory, and Cultural Identity', which aims to assess the role of popular music in the negotiation of cultural identity in a local, national and European context (Brandellero, Janssen, Cohen and Roberts, 2014). For this specific study, we analyzed a 
subset of interviews, focusing on the role of museums and archives in the construction of popular music as a form of cultural heritage.

To examine how Dutch museums and archives engaging in popular music heritage practices give form to understandings of place and local cultural identity, we conducted 15 semi-structured interviews (see table 1). ${ }^{1}$ We used a purposive sampling strategy, in order to select and interview respondents who represent a diverse range of heritage practices. This allowed us to explore variations in museums and archives in terms of their focus on popular music, level of institutionalization and geographical scale. In line with the democratization of heritage practices discussed above, we interviewed both professional and non-professional heritage practitioners (i.e. DIY preservationists). As seen in table 1, the institutional set-ups of the organizations differ. From the funding perspective, we note the variation from temporary exhibitions in publicly-funded museums and collections in subsidized institutes, to privately-driven collections and archives. As the Netherlands is a small country, we were able to study all the main players in the field of popular music heritage on the national level. We interviewed representatives of key organizations such as Museum RockArt, Music Center the Netherlands and the POPstudio of the Netherlands Institute for Sound and Vision. In the case of the local music heritage initiatives, we achieved a representative sample in terms of geographical spread by selecting projects from different parts of the Netherlands. This diverse sample facilitated the process of comparing and contrasting their aims and work practices (Corbin and Strauss, 1990).

In collaboration with researchers from three other countries involved this project, a topic guide was constructed for the interviews with museum curators and archivists (see Appendix A). This list contains questions on the aims and objectives of the organizations, the content of their collections, understandings of cultural heritage and the personal perspective of the respondents (e.g. music tastes and their career trajectory). Additionally, and in accordance with our research question, we explored the meaning of place in their practices. However, as not all projects are defined in geographical terms, the interviews also addressed other ways of framing popular music history such as by genre or period. The list of topics guided the interviews, but we gave enough room to respondents to foreground their own ideas and perspectives. On average, the interviews lasted around an hour. All interviews were conducted face-to-face with the exception of two phone interviews (Streektaalzang and

\footnotetext{
${ }^{1}$ The 15 interviews represent 16 projects, as one person is active in both the Stempel Broodje Archive and the Offshore Radio Club.
} 
Drents Museum). These two interviews were somewhat shorter and focused more on the aims and objectives of their respective music heritage activities. Five interviews were done together by the two authors of this article. This allowed us to compare our impressions and interpretations and as such guard against bias (Corbin and Strauss, 1990). We agreed with the respondents to not mention their names in publications.

Table 1 - Overview of the interviews with curators and archivists

Museums / Exhibitions
Museum RockArt (Hoek
van Holland)

'Geef mij maar
Amsterdam' (Amsterdam
Museum)
God Save the Queen-
Art, Squatting, Punk:
1977-1984 (Centraal
Museum, Utrecht)
Special request-Cuby
and the Blizzards in the
sixties (Centraal
Museum, Utrecht)
POPstudio (The
Netherlands Institute for
Sound and Vision,
Hilversum)
Drents Museum (Assen)

Description

Year $^{2}$

Private museum with a permanent exhibition, tracing the history of

Dutch popular music from 1950 to nowadays, and occasional temporary exhibitions on prominent national and international artists and movements.

Temporary exhibition on the history of the city of Amsterdam through song from the XVII century to nowadays.

Temporary exhibition providing local, national and international perspectives on the visual arts, music and social movements of the late 1970s and early 1980s. The exhibition used materials from the 'Stempel Broodje' collection (see below).

Temporary exhibition on the Dutch blues band Cuby and the Blizzards, curated by an employee of the Utrecht Centraal Museum in honour of 25 years in service. The exhibition is primarily based on collector loans and material from the Cuby and the Blizzards museum in Grolloo.

Permanent exhibition of audiovisual material on Dutch popular music, taken from the video archives of the Dutch Institute for Sound and Vision, where POPstudio is housed.

Museum of Drenthe, a rural province located in the North-East of the Netherlands. The museum acquired a private collection on the Dutch blues band Cuby and the Blizzards.

Golden Earring - Back Home (Historical Temporary exhibition on the band Golden Earring, which originated in The Hague. The exhibition showcased material from the archives of the Museum, The Hague)

Flower Power (Museum Limburg, Venlo) Rock Art Museum, as well as from other collectors.

Temporary exhibition on the youth culture of the 1960s and 1970s. Music is one of the main themes in this exhibition hosted by the provincial museum of Limburg.

\section{Archives}

Description

Pop archive Achterhoek/ Group of music experts and fans, connected to the local heritage Liemers organization, charting the music history of the rural region of Achterhoek en Liemers. They have published the gathered knowledge in a number of books.

Stempel Broodje

Private collection on the punk movement. One of the founders (Stempel) is involved in the Offshore Radio Club (see below). Their material was used in the travelling Europunk exhibition and the punk exhibition in Centraal Museum Utrecht (see above).

Music Center the Netherlands

Resource, research and promotion center and archive for Dutch music. Closed in December 2012 due to its public subsidies being cut. MCN was formed in 2008 following the merger of a number of genre-specific institutes, including the National Pop Institute set up in 1975.

\footnotetext{
${ }^{2}$ Indicates year of exhibition, or in the case of archives, year of establishment.
} 

broadcasts from the offshore radio station Radio Veronica, from 1959 to 1974 . The website has a members-only, subscription-based section.

Streektaalzang

Het Geluid van Rotterdam

Offshore Radio Club

Zaanse pophistorie
Online archive on Dutch dialect music, organized by region, curated by a private individual.

Organization aiming to preserve and promote music from Rotterdam.

Online archive, finding and preserving recordings, photos and histories from all European offshore radio stations programmes from the mid1960s to mid-1970s. The website has a restricted section for members only.

Online archive providing information and visual resources on the bands and music venues of the Zaanstreek region located North of Amsterdam, from 1958 to nowadays.

In addition to the interviews, the following museums and exhibitions were visited: Museum RockArt, God Save the Queen - Art, Squatting, Punk: 1977-1984, Special request - Cuby and the Blizzards in the sixties, POPstudio, Golden Earring - Back Home, Flower Power and Design as Politics. ${ }^{3}$ Noting observations and taking photographs, we focused on the way in which popular music history is framed, how objects were displayed and how these objects were explained to the audiences. The photographs taken at the exhibitions and the transcripts of the interviews were loaded into Atlas.ti, a computer program for qualitative data analysis. This allowed us to explore, compare and classify the data using an open coding strategy. In a second stage, we clustered codes and identified recurring patterns and central themes in the data. This led to a typology of ways in which the connections between place and popular music heritage are formed in the practices of the studied projects.

\section{Research Findings}

In the following sections, we present our research findings. First, we discuss the organizational setting of the projects we analyzed, before then turning to the ways in which places are remembered through these practices of museums and archives. Finally, we examine how museum curators and archivists place their practices in the local-global nexus the localized preservation of a global cultural form entails.

\subsection{Organizational perspective}

The impetus behind the setting-up of archives is often provided by avid collectors and fans, most frequently working independently and driven by their own personal interest. The smaller-scale initiatives corroborate the finding of Flinn et al. (2009, p. 78) that "most of

\footnotetext{
${ }^{3}$ The Design as Politics exhibition, which addressed music's connection to urban regeneration, was held in Rotterdam in 2012. For this exhibition we did not interview the curator.
} 
these archives generally reflect the founding ideals and motivations of a few key individuals." In this respect, we note a varying degree of professionalization and institutionalization of amateur preservation practices among the archives, particularly in the cases where the sheer size of some private collections called on respondents to address practical issues of conservation and sustainability. Indeed, Crooke (2007) finds that bottom-up heritage initiatives eventually can take on characteristics of more 'official' heritage organizations. Nevertheless, established cultural institutions generally have more resources at their disposal, a higher level of formalization, as well as greater cultural legitimacy (Roberts and Cohen, 2014), whereas DIY practices mainly rely on the efforts of volunteers.

However, we observe a frequent level of collaboration between amateurs and professional institutions, as in the case of the mobilization of knowledge and resources of fans and private collectors in museum exhibitions. For example, the director of the Museum RockArt was guest curator of the Golden Earring exhibition in the Hague Historical Museum, participating in the ideation, planning and implementation of the project, while also providing the vast majority of items on display.

The preservation practices of the organizations we studied primarily centered around exhibiting and archiving, but also branched out to a variety of other outputs, ranging from books (Pop archive Achterhoek / Liemers), concerts (Norderney Foundation and Pop archive Achterhoek / Liemers) to radio shows (Zaanse pophistorie, Norderney Foundation and Pop archive Achterhoek / Liemers). Moreover, one output lead to another, often in ad-hoc rather than a clearly planned way.

The organizations also range in terms of their geographical and historical remits, from rural areas to cities, from time and place-bound exhibits to country and century spanning collections. However, the processes of remembering that we will now discuss are, unless explicitly stated, largely similar on the different geographical scales.

\subsection{Remembering places through music}

In our analysis of how the popular music heritage practices of museums and archives give form to understandings of place and local cultural identity, three main themes emerge: the framing of local sociocultural histories through popular music; the contribution of popular music to a sense of belonging in local communities; and the documenting of the artistic legacy of place. In the following, these themes will be further discussed and analyzed. 


\subsubsection{Music as a local timeline}

Firstly, in the practices of museums and archives, music is used to present local histories, drawing on the musical memories attached to specific places. As a curator of the Historical Museum of the Hague explains:

We are a city museum, so our mission [...] is (to) present the story, or the many stories, because there are more, of the city in connection to the people who live here. [...] Of course, if you look at a city there are many aspects to it that represent the identity or the cultural expressions, and looking at The Hague one of the typical things that is often said of its modern history is that it is also an important musical city. (Historical Museum of The Hague)

In similar terms, the curator Contemporary Art of a provincial museum in Drenthe justifies the acquisition of a private collection on local band Cuby and the Blizzards and their singer Harry Muskee. He argues that this band has made a significant contribution to the music history of this province.

We collect everything related to the history of this province, which also applies to music. [...] Of course, Muskee and Cuby is extraordinary for Drenthe, especially if you look at it from the vantage point of the 1960s. They had a very important role in the emergence of blues in the Netherlands. (Drents Museum)

In contributing to the delineation of local histories, as the director of Museum RockArt describes, music functions as a 'timeline', giving an overview of sociocultural developments in the Netherlands and the ways in which music is connected to these happenings. The term timeline is telling, because it designates that popular music is bound up with changes and important events in social-cultural life. Therefore, re-listening to old music might evoke memories of long gone times and places. This could be on an individual level (DeNora, 1999), when music invokes personal memories of childhood or previous places of residence. However, these recollections might also be widely shared because they constitute the cultural life of a generation (Van Dijck, 2006). In this respect, Bennett (2009, p. 486) describes how rock has become part of the trans-national cultural heritage of the baby-boomer generation, understood as a significant turning point in Western culture of the late XX century, beyond its 
association with memories of youth. However, in the heritage practices we studied these memories of the baby-boomer generation are generally presented from a local perspective, focusing on Dutch bands, radio stations, music magazines and countercultural activities in the Netherlands of the 1960s.

While providing a timeline, music draws a map filled with spatial references embedding cultural memories in places, be they still existing or remembered. Songs are an essential part of these collections, because they often relate to local themes and events. An exhibition on music and architecture ${ }^{4}$, for instance, presents songs that have engaged with processes of urban regeneration and their social effects. Thus, music and lyrics are able to represent for instance the cultural landscapes or city life of particular periods (Cohen, 1995). Furthermore, since music is consumed in concert halls, houses, cafes and festival sites, it is part of the built environment of places. The intensity of musical experiences in these places, as well as their emotional and cultural relevance, explains that archivists and collectors take great pains to record their histories. In his motivation for documenting the music history of the Zaanstreek, a region in the north of the Netherlands, this archivist explicitly refers to these places of musical activity:

Zaanstreek is seven small towns, but in the 1960s there were big venues in the small towns. Small cafes on the streetsides, but then at the back would be a big venue. A lot of big bands from the Dutch scene in the 1960s came to the Zaanstreek to play; a lot of action. (Zaanse Pophistorie)

Like similar initiatives, the website of this archive features personal memories, tickets and photos of these places. Although in a lot of cases the venues no longer exist, their legacy is preserved through the practices of these archives.

\subsubsection{Music and local belonging}

Secondly, by recording local histories, museums and archives actively contribute to the identity of particular localities and as such 'produce places' (Cohen, 1995; Hudson, 2006). As a form of city-marketing, popular music heritage can make places more attractive to visitors (Brandellero and Janssen, 2014). However, these heritage practices are also oriented towards

\footnotetext{
${ }^{4}$ Design as Politics, an exhibition held in Rotterdam in 2012.
} 
the communities inhabiting localities. Popular music heritage is related to shared experiences that foster a sense of belonging in local communities. These attachments to place enhance social cohesion and feelings of community (Gieryn, 2000). Music constitutes local identities, as areas or cities are often known for particular genres and musicians originating from these localities. Museums and archives preserve and present music-related memories and thus perpetuate what Bennett (2002) calls the myths of these places. The Dutch town Volendam, for instance, is known for its Palingsound ('Eel sound'), which refers to the economic activity of fishing in this village as well as the 'sleek' sound of the artists from Volendam (Schuyt and Taverne, 2004). This label was first used in the 1960s and journalists still employ it to describe current artists (Mutsaers, 2001). In a museum located in the attic of a local seafood restaurant, the history of the Palingsound is presented to tourists visiting Volendam. Another example of the production of place is the popularity of blues in Drenthe, a province in the north-east of the Netherlands. As also explained by the curator cited above, in particular the band Cuby and the Blizzards has contributed to the music culture of this province. A farm in the small village Grolloo, where the band recorded the critically acclaimed and aptly-titled album Groeten uit Grollo ('Greetings from Grolloo'), now hosts a museum dedicated to their legacy.

As these practices of museums and archives foster a sense of belonging in local communities (Long and Collins, 2012), they concurrently demarcate how a place differs from others. The curator of the Cuby and the Blizzards exhibition at Centraal Museum Utrecht, for instance, reflected on how the band is bound up with distinctions between the cultural center of the Netherlands and the more rural region the band is from.

I like it that they started in the 1960s, and in the 1960s the pop music was The Hague, Amsterdam, Rotterdam and they came from out of the bush. The farmers they said here, but the farmers played the whole nederbeat down, they were the best. (Curator Exhibition 'Special Request', Centraal Museum)

According to Schuyt and Taverne (2004, p. 411), "Cuby developed an entirely individual, sober variant of the blues, which fans quickly identified with the rural and provincial culture of Drenthe, devoid of metropolitan hecticness." Echoing this, the curator of the museum that acquired a private collection of Cuby and the Blizzards material, further explains how this distinction from other localities is related to a sense of pride and local identity. 
Everyone was proud of Muskee and his group; in that sense this transcends the music itself. Their local roots in the province of Drenthe are very important, perhaps also for the self-awareness of the region. [...] This has to do with pride and a certain mentality. This group has been very important in that respect and this is why their LPS and singles, and the rest of the collection, belong to the cultural heritage of Drenthe. (Drents Museum)

Local musicians can thus enhance the self-consciousness and pride in a region, for example by singing in a local dialect (Grijp, 2007) or acknowledging their roots. Although in the case of Cuby and the Blizzards this sense of pride concerns an urban/rural divide, music is also mobilized in the rivalry and distinction between cities. For instance, contrary to 'rival city' Amsterdam, Rotterdam is not readily recognized for its cultural achievements (Van Ulzen, 2007). For this reason, the project description of a popular music archive in Rotterdam states "fostering a sense of pride" as one of the main aims (Van der Most, 2011). Such cultural pride is particularly relevant to communities who feel their heritage is not adequately represented in dominant narratives. Heritage discourses are then invoked to achieve recognition of particular identities and legacies (Anico and Peralta, 2009). According to Regev (2007), these claims for difference and recognition can be understood as a consequence of the fragmentation of national identities into a multiplicity of identities based on, amongst other variables, ethnicity and lifestyle. Similarly, Misztal (2003, p. 18) argues: "The processes of globalization, diversification and fragmentation of social interests further enhance the transformation of memory from the master narrative of nations to the episodic narrative of groups." Through narratives of music heritage, local communities try to affirm a sense of uniqueness and difference.

\subsubsection{Music and the representation of local artistic diversity}

The third theme that emerged from our data is that these heritage projects preserve and present the artistic legacy of places. They document the different artists that have contributed to local cultural landscapes. Particularly in the case of the local community archives, this is also about remembering different things from the well-known national histories. They focus not just on the popular artists, but also the unknown and long-forgotten ones. An archivist of Pop archive Achterhoek/Liemers explains that in their publications they raise awareness of artists who usually get less attention: 
Enough has been written on Normaal ${ }^{5}$ and Vandenberg ${ }^{6}$, so for once we wanted to move the spotlight on bands which are under the radar...It's surprising what you come up with. (Pop archive Achterhoek/Liemers)

Of course, the dominant histories of popular music ignore the many artists that often only achieved regional success (Hayes, 2006). However, Hayes nevertheless highlights their cultural significance as these less successful musicians "contributed significantly to the development of rock and roll and its numerous subgenera by expanding teen audiences, experimenting with musical forms and, perhaps most importantly, serving as models for other youth who would subsequently form their own bands".

The democratization of heritage practices allows local community archives to question received narratives as they are presented by nationally oriented media. Archivists and curators want to represent the musical diversity of specific localities by giving detailed overviews of the music histories of specific places. In an encyclopedic fashion, archivists try to collect and preserve all the information about local music history. This shows how popular music is mobilized to put places on the map and promote the cultural accomplishments of these localities.

\subsection{Negotiating the local and the global in popular music heritage}

So far, this study has looked at the meanings and objectives of the practices of museums and archives for places within the Netherlands. However, as Cohen (2013, p. 590) argues, popular music transcends the local: "As a global, mass-mediated and highly mobile, travelling culture, it also has iconic and transnational appeal, and has inspired multiple, hybrid and cosmopolitan cultures and identities." The practice of preserving popular music as heritage reveals a tension particular to this cultural form which is, as we have seen, at once situated in local social histories and connected to global cultural flows. In this section we discuss how this tension comes to the fore in three ways: first, in the drawing of spatial boundaries in collections; secondly, in the local adaptation of global music trends; and finally in the comparison between developments in the Netherlands and abroad.

\subsubsection{The local as a selection boundary}

\footnotetext{
${ }^{5}$ Normaal gained national fame in the Netherlands with their rock songs sung in a local dialect.

${ }^{6}$ Hard rock band Vandenberg scored an international hit with Burning Heart.
} 
While as we noted place is often used to define the boundaries of collections and exhibitions, the focus on single localities can miss out on the interrelations between them, and their wider context. According to Massey (1995b, p. 59) place in fact functions "as a meeting-place, the location of the intersections of particular bundles of activity spaces, of connections and interrelations, of influences and movements." However, in the heritage practices of curators, the boundaries of localities function as practical instruments facilitating processes of selection of materials and allowing a more justifiable 'cut-off' point in collections. Yet, defining boundaries around place raises questions on how to engage in the preservation and representation of popular music heritage in a practical and inclusive way.

The local as boundary acts on the one hand as a selection criteria, prioritizing local music production and consumption histories. On another level though, the local as boundary functions as a way to focus on the local consumption of foreign popular music, embedding it in the history of places and local institutions, as evident in the following quotes:

The only interesting book [on the Beatles] for our collection, and there are two, is 'the Beatles in Holland'; then it is interesting. Then it is a very specific Dutch view on foreign artists. (Archivist Music Center the Netherlands)

And we always keep in mind that the things we show here have to be special in a way; that they don't show up on YouTube or something, it has to be unique. It needs to have a relation to the broadcasting history of Holland. (POPstudio, The Netherlands Institute for Sound and Vision)

Although the music itself might come from abroad, it is consumed through local and national media and in music venues that are located in particular cities, rendering it uniquely local (Kuipers, 2013; O'Flynn, 2007). The framing of the global history of popular music through a local and national prism also resonates with the 'imagined communities' (Anderson, 1991) that institutions such as media, museums and archives cater for. This process is reinforced by the fact that funding for heritage institutions often comes from local and national funding organizations (as is the case of the Netherlands Institute for Sound and Vision, which focuses on the Dutch broadcasting history). Increasingly, these funds expect museums to actively connect to communities in order to enhance their impact and attract more visitors (Crooke, 2007). 


\subsubsection{The local as global adaptation}

While archivists and curators try to bring to the fore the local and national manifestations of popular music, in their practices they are also confronted with what Kaplan (2012) refers to as the 'translation as erasure'. As global cultural forms such as music are adopted in particular countries and integrated in local processes of production, their foreign roots are concealed (i.e. erased) beneath a layer of local and national meanings. While musical styles might have foreign roots, when they are taken up by artists from the Netherlands or sung in the Dutch language or one of its dialects, they become embedded in local identities (Grijp, 2007; Van der Hoeven, Janssen and Driessen, forthcoming). Placing local music in a wider context helps to reveal these connections: a recent exhibition on Dutch punk, focusing on its relation to squatting and art, attests to the added value of bringing music artefacts from different places together. According to the curator of this exhibition, such an approach helps to reveal the local connection to global art forms and movements:

I was interested in giving international connections, because I didn't want the image as if the Netherlands was a sort of island, an isolated island. The Netherlands has always been a haven, a harbour for all kinds of influences, and especially in music it is very strong. Of course you can't think of, you know, of all these bands here without the bands in New York, especially New York, London or in Germany. (Curator exhibition 'God Save the Queen', Centraal Museum)

The inter-connection between the local and the wider context also came to the fore in an exhibition on the 1960s, hosted by the Limburg region's local history museum. This exhibition presented popular music as a central aspect of the region's youth culture in the 1960s, drawing a comparison between the local Pinkpop festival and its American precursor Woodstock.

I: Clearly, the exhibition looks at developments in Limburg and The Netherlands, but Woodstock as well. So there are different levels. How did you handle this?

$R$ : That took some consideration indeed. As a museum of the Limburg region, are you only going to focus on Limburg, or also the Netherlands and the international aspects? I found it impossible to only focus on Limburg. We are talking about influences that manifest themselves in Limburg, but have their roots somewhere else and spread on a global scale. (Curator Limburgs Museum) 
Preserving and displaying local music histories therefore triggers curators and archivists to reflect on the nature of the 'local' and how it resonates within global cultural phenomena. Finding global communalities and local specificities forms an integral part of cherishing the contribution of Dutch artists to international popular music developments.

\subsubsection{Comparing the local, in the Netherlands and abroad}

Museums and archives give places meaning by engaging with the particular ways in which international developments such as punk and hippie culture resound into specific localities. This shows that globalization and local identification are not antithetical phenomena (Kaplan, 2012), but stand in a reciprocal relation. The global thus serves as a point of comparison for local developments. As a result of the international success of bands like the Golden Earring and Q65, the exhibition on the former at the Historical Museum of The Hague described the city as 'the Liverpool of the Netherlands'. This shows that narratives of popular music heritage often revolve around local manifestations of global phenomena. An example of this is the travelling exhibition Europunk, which explored the visual aspects of punk in different countries. As a collector, who lent material to this exhibition, argues:

When you are in the Netherlands you do not notice that there are so many similarities between things happening in separate places. [...] If you compare the posters or fanzines from Italy with those from the UK or the Netherlands the similarities are striking. (Private collector)

Moreover, non-local success is often used as a measure to assess the significance of Dutch artists, as exemplified in '50 years of Nederpop', a canon of Dutch popular music history put together in collaboration with Music Center the Netherlands (Brandellero and Pfeffer forthcoming; Stichting 50 jaar Nederpop, 2008). Canon entries such as "the whole world sings Ramona", and Jan Akkerman "guitar God from the Netherlands", celebrate the recognition of local popular music abroad, adding meaning to the local by virtue of its international reverberation. Success abroad, as well as comparison to internationally renowned events or developments, thus feeds back into the meanings attached to local music histories, mustering a sense of pride in the achievements of homegrown talent and in the international parallels they draw upon (see Brandellero and Pfeffer, forthcoming).

\footnotetext{
${ }^{7}$ A song by the Blue Diamonds.

${ }^{8}$ This refers to Jan Akkerman, guitarist for Brainbox and Focus.
} 


\section{Conclusions}

The aim of this article has been to examine how the collection and display of popular music heritage in Dutch archives and museums gives form to understandings of place and local cultural identity. This study follows on from three developments in the field of heritage: the increasing attention to the heritage of marginalized groups, the emergence of bottom-up forms of heritage, and the challenges to notions of local identities due to processes of globalization. Understandings of heritage as the expression of a fixed, national identity have been called into question because national cultures have become more open to influences from other countries through mass media, the circulation of cultural products and migration. Therefore, several authors argue that as a result of this international orientation the identifications with popular music have become more likely to transcend local or national identities (Bennett, 2009; Regev, 2007).

Notwithstanding the global character of the music industry, our findings suggest that place continues to be a central way in which music history is framed. Place is often used by cultural gatekeepers to define the boundaries of collections and in order to frame the history of popular music from a local perspective. On the basis of the analysis of our data, we conclude that the popular music heritage practices of Dutch museums and archives give place meaning through three interrelated processes.

Firstly, museums and archives present local sociocultural history through the archiving and display of popular music from the past. Popular music heritage thus positions communities in physical place. Through the local consumption of popular music in pubs and music venues, it becomes part of the built environment and the cultural memories attached to these places. As such, popular music heritage provides a timeline of the sociocultural developments in particular places.

Secondly, their heritage practices resonate with local identities and foster a sense of cultural pride. Local archives and museum aim to preserve popular music heritage as an expression of place-bound cultural identities. This presentation of local cultural uniqueness and identity manifests itself in urban-rural divides, rivalry between cities and even in the music styles associated with particular neighborhoods.

Thirdly, these practices document the artistic legacy of place. In the current study it was found that popular music heritage is about communicating musical successes and the 
contributions of specific places to the general development of popular music. In so doing, archivists and curators often raise awareness of artists that are overlooked in 'mainstream narratives' or want to show that their local music culture is more diverse than is generally thought.

Together, these three processes constitute the locally oriented selection mechanisms of cultural gatekeepers. This reveals a tension between the local and the global, as curators of museums and archives draw spatial boundaries by focusing on the local adaptation of global music trends and make comparisons between developments in the Netherlands and abroad. As cultural institutions cater for local and national communities, this affects the ways in which popular music history is framed by these organizations. However, the narrow orientation on specific places can also pose limits to understanding of popular music history. It might neglect the musical connections between different places or the contributions of migrants to local or national cultures (Khabra, 2014). This study posits that popular music heritage implicates a reciprocal relation between the global and local. As a global cultural form, popular music is appropriated in particular places and acquires specific local meanings which are shared by communities. Dutch museums and archives strongly connect to experiences of popular music consumption in everyday life, for instance by presenting Dutch media such as radio stations, television programs and magazines, through which foreign artists reached audiences in the Netherlands.

As this study concerned the role of cultural gatekeepers in mediating attachments to place, further research is required to address how audiences interpret these narratives of popular music and heritage. Furthermore, since this article was particularly focused on local and national heritage practices, future research could explore transnational ways of framing popular music history. Travelling exhibitions and multi-lingual heritage platforms like Europeana are potentially more international ways of presenting the cultural past (Van der Hoeven, 2015). Further research is also needed on the various factors that impact upon the ways in which cultural histories are framed and heritage practices are organized, such as cultural policies and funding schemes. Since identities and cultural styles increasingly transcend national borders, both researchers and heritage practitioners have to be sensitive to the sociocultural relations between places on various geographical scales. 


\section{Acknowledgements}

This research has been supported as part of the Popular Music Heritage, Cultural Memory and Cultural Identity (POPID) project by the HERA Joint Research Program (www. heranet.info) which is co-funded by AHRC, AKA, DASTI, ETF, FNR, FWF, HAZU, IRCHSS, MHEST, NWO, RANNIS, RCN, VR and The European Community FP7 20072013, under 'the Socio-economic Sciences and Humanities program'. The authors would like to thank Balázs Boross, Olivier Nyirubugara, Susanne Janssen, the anonymous reviewers and the editors of Poetics for their valuable comments and suggestions.

\section{References}

Achterberg, P., Heilbron, J., Houtman, D., Aupers, S., 2011. A Cultural Globalization of Popular Music? American, Dutch, French, and German Popular Music Charts (1965 to 2006). American Behavioral Scientist 55 (5), 589-608.

Anderson, B. 1991. Imagined communities. London: Verso.

Anico, M., Peralta, E. 2009. Introduction. In: Anico, M., Peralta, E. (Eds.), Heritage and Identity: Engagement and Demission in the Contemporary World. London : Routledge, pp. 1-11.

Appadurai, A., 1990. Disjuncture and difference in the global cultural economy. Public culture $2(2), 1-24$.

Ashworth, G.J., 1994. From history to heritage - from heritage to identity: in search of concepts and models. In: Ashworth, G.J., Larkham, P.J. (Eds.), Building a new heritage. Tourism, culture and identity in the New Europe (pp. 13-30). London: Routledge.

Ashworth, G. J., Graham, B. J., Tunbridge, J. E., 2007. Pluralising pasts: heritage, identity and place in multicultural societies. London: Pluto Pr.

Assman, J., Czaplicka, J., 1995. Collective memory and cultural identity. New German Critique 65, 125-133.

Baym, N.K., Burnett, R. 2009. Amateur Experts: International fan labour in Swedish independent music. International Journal of Cultural Studies 12(5): 433-449.

Bennett, A., 2002. Music, media and urban mythscapes: a study of the'Canterbury Sound'. Media, Culture \& Society 24 (1), 87. 
Bennett, A., 2009. "Heritage rock": Rock music, representation and heritage discourse. Poetics 37 (5-6), 474-489.

Bennett, T., 1995. The birth of the museum: history, theory, politics. London: Routledge.

Brandellero, A., Janssen, S., 2014. Popular music as cultural heritage: scoping out the field of practice. International Journal of Heritage Studies 20(3), 224-240.

Brandellero, A., Janssen, S., Cohen, S., Roberts, L. 2014. Popular music heritage, cultural memory and cultural identity. International Journal of Heritage Studies, 20 (3), 219-223.

Brandellero, A., Pfeffer, K., forthcoming. Making a Scene: Exploring the dimensions of place though Dutch popular music, 1960-2010. Environment and Planning A [accepted for publication].

Cohen, S., 2013. Musical memory, heritage and local identity: remembering the popular music past in a European capital of culture. International journal of cultural policy 19(5), 576-594.

Cohen, S., 1995. Sounding out the city: music and the sensuous production of place. Transactions of the Institute of British Geographers 20, 434-446.

Corbin, J. M., \& Strauss, A., 1990. Grounded theory research: Procedures, canons, and evaluative criteria. Qualitative sociology 13 (1), 3-21.

Crane, S.A., 1997. Writing the individual back into collective memory. The American Historical Review 102 (5):1372-1385.

Crane, D., 2002. Culture and globalization: Theoretical models and emerging trends. In D. Crane, N. Kawashima \& K. Kawasaki (Eds.), Global Culture (pp. 1-26). London: Routledge

Crooke, E. M., 2007. Museums and community: ideas, issues and challenges. London ; New York: Routledge.

DeNora, T., 1999. Music as a technology of the self. Poetics 27 (1), 31-56.

Emerick, K., 2009. "Archaeology and the cultural heritage management 'toolkit': the example of a community heritage project at Cawood, North Yorkshire”. In: Taking archaeology out of heritage, Waterton, E., Smith, (Eds.), L. Newcastle-upon-Tyne: Cambridge Scholars Press, pp. 91-116.

Featherstone, M., 2006. Archive. Theory, Culture \& Society 23 (2-3), 591-596.

Flinn, A., 2007. Community Histories, Community Archives: Some Opportunities and 
Challenges. Journal of the Society of Archivists 28 (2), 151-176.

Flinn, A., Stevens, M., \& Shepherd, E., 2009. Whose memories, whose archives? Independent community archives, autonomy and the mainstream. Archival Science 9 (1), 71-86.

Fraser, N. 2001 Recognition without ethics? Theory,Culture and Society 18 (2-3), 21-42.

Grijp, LP., 2007. Singing in Dutch dialects: language choice in music and the dialect renaissance. In: Magry, P.J. \& Roodenburg, H., (Eds.) Reframing Dutch Culture: Between Otherness and Authenticity. Aldershot, England: Ashgate, pp. 225-243.

Gieryn, T. F., 2000. A Space for Place in Sociology. Annual Review of Sociology 26, 463496.

Graham, B., Ashworth, G., \& Tunbridge, J., 2000. A geography of heritage: Power, culture, and economy. London: Arnold.

Hall, S., 1999. Whose heritage? Un-settling "the heritage", re-imagining the post-nation. Third Text, 13(49), 3-13.

Hall, S., 2001. Constituting an archive. Third Text 54 (15), 89-92.

Hayes, D. 2006. 'Take those old records off the shelf': youth and music consumption in the postmodern age. Popular Music and Society 29(1): 51-68.

Hoebink, D., 2011. Globalisation, the Community Museum and the Virtual Community. In: Halbertsma, M., Stipriaan, van A., \& Ulzen, van P., (Eds.), The Heritage Theatre. Globalisation and Cultural Heritage. Newcastle upon Tyne: Cambridge Scholars, pp. 133-150.

Howard, P., 2003. Heritage: management, interpretation, identity. London: Continuum.

Hudson, R., 2006. Regions and Place: Music, Identity and Place. Progress in Human Geography 30 (5), 626-634.

Janssen, S., Kuipers, G. \& Verboord, M., 2008. Cultural Globalization and Arts Journalism. The international orientation of arts and cultural coverage in Dutch, French, German, and U.S. newspapers, 1955 to 2005. American Sociological Review 73 (5), 719-740.

Kaplan, D., 2012. Institutionalized erasures: How global structures acquire national meanings in Israeli popular music. Poetics 40(3), 217-236. 
Kaplan, E., 2000. We are what we collect, we collect what we are: archives and the construction of identity. American archivist 63(1), 126-151.

Khabra, G., 2014. Music in the margins? Popular music heritage and British Bhangra music. International Journal of Heritage Studies 20(3), 343-355.

Kong, L., 1997. Popular music in a transnational world: the construction of local identities in Singapore. Asia Pacific Viewpoint 38 (1), 19-36.

Kuipers, G., 2013. The rise and decline of national habitus: Dutch cycling culture and the shaping of national similarity. European Journal of Social Theory 16(1), 17-35.

Leonard, M., 2010. Exhibiting popular music: museum audiences, inclusion and social history. Journal of new music Research 39 (2), 171-181.

Lidchi, H., 1997. The poetics and the politics of exhibiting other cultures. In: Hall, S. (Ed.), Representation: Cultural representations and signifying practices. London: Sage, pp. 151-222.

Long, P., Collins, J., 2012. Mapping the Soundscapes of Popular Music Heritage. In: Robberts, L, (Ed.), Mapping Cultures: Place, Practice, Performance. Basingstoke: Palgrave Macmillan, pp. 144-159.

Massey, D., 1995. The conceptualization of place. In: Massey, D., Jess. P., (Eds.). A place in the world? Places, Cultures and Globalization. Oxford: Oxford University Press, pp. 45-85.

McLean, F. and Cooke, S., 2000. Communicating National Identity: Visitor Perceptions of the Museum of Scotland. In J. M. Fladmark (Ed), Museums and Cultural Identity: Shaping the image of nations. Shaftesbury: Donhead, pp. 147-160.

Merriman, N., 1991. Beyond the Glass Case: The Past, the Heritage and the Public in Britain. Leicester: Leicester University Press.

Misztal, B., 2003. Theories of Social Remembering. Maidenhead: Open University Press.

Moore, K., 1997. Museums and popular culture. London: Cassell.

Moore, S., Pell, S., 2010. Autonomous archives. International Journal of Heritage Studies 16 (4-5), 255-268.

Morley, D., 2001. Belongings: Place, space and identity in a mediated world. European Journal of Cultural Studies 4 (4), 425.

Mutsaers, L., 2001. Opkomst en achtergronden van de palingpop [The rise of the Eel Sound]. In: Grijp, L.P. (Ed.) Een muziekgeschiedenis der Nederlanden. Amsterdam: Amsterdam University Press, pp. 737-742. 
Newman, A., McLean, F., 2006. The impact of museums upon identity. International journal of heritage studies 12(1), 49-68.

O'Flynn, J., 2007. National identity and music in transition: Issues of authenticity in a global setting. In: I. Biddle \& V. Knights (Eds.), Music, national identity, and the politics of location. Burlington, VT: Ashgate, pp. 19-38.

Perin, C. 1992. The communicative circle: museums as communities. In: Karp, I., Kreamer, C., and Lavine, S. (Eds). Museums and communities. The politics of public culture, Smithsonian Institution Press, Washington, pp. 182-220.

Regev, M., 2007. Cultural Uniqueness and Aesthetic Cosmopolitanism. European Journal of Social Theory 10 (1), 123-138.

Roberts, L., Cohen, S. 2014. Unauthorising popular music heritage: outline of a critical framework. International journal of heritage studies 20(3): 241-261.

Schwartz, J.M., Cook, T., 2002. Archives, records and power: the making of modern memory. Archival Science 2 (1-2), 1-19.

Smith, L., 2006. The Uses of Heritage. London: Routledge

Smith, L., 2010. Ethics or social justice?: heritage and the politics of recognition. Australian Aboriginal Studies 2: 60-68.

Snoek, C. G. M., Freiburg, B., Oomen, J., Ordelman, R., 2010. Crowdsourcing rock n' roll multimedia retrieval. Proceedings of the international conference on Multimedia, MM '10. New York, NY: ACM, pp. 1535-1538.

Schmutz, V., Venrooij, A. van, Janssen, S., Verboord, M., 2010. Change and continuity in newspaper coverage of popular music since 1955: Evidence from the United States, France, Germany, and the Netherlands. Popular Music and Society 33 (4), 501-515.

Schuyt, K. and Taverne, E., 2004. Dutch culture in a European perspective: 1950 prosperity and welfare. Hampshire: Palgrave.

Stevens, M., Flinn, A., \& Shepherd, E., 2010. New frameworks for community engagement in the archive sector: from handing over to handing on. International Journal of Heritage Studies, 16(1-2): 59-76.

Stichting 50 jaar Nederpop. (2008). 50 jaar Nederpop. Canon van de Nederlandse popmuziek [Dutch popular music canon]. Stichting 50 jaar Nederpop \& Muziek Centrum Nederland.

Van der Most, E., 2011. Het Geluid van Rotterdam [The Sound of Rotterdam]: Project Plan. 
Van den Bosch, A., 2007. Museums: Constructing a public culture in the global age. In:

Watson, S. (Ed.), Museums and their communities. London \& New York:

Routledge, pp 501-509.

Van der Hoeven, A., 2015. Remembering the 1960s: popular music and memory in Europe. International Journal of Cultural Policy, 21(3), 258-272

Van der Hoeven, A., Janssen, S. \& Driessen, S., Forthcoming. Articulations of identity and distinction: The meanings of language in Dutch popular music. Popular Music and Society [accepted for publication].

van Dijck, J., 2006. Record and Hold: Popular Music between Personal and Collective Memory. Critical Studies in Media Communication 23 (5), 357-374.

Van Ulzen, P., 2007. Imagine a metropolis: Rotterdam's creative class, 1970-2000. Rotterdam: 010 Publishers.

Waterton, E., \& Smith, L.. 2010. The recognition and misrecognition of community heritage. International Journal of Heritage Studies, 16(1-2), 4-15.

Weil, S., 1997. The museum and the public. Museum management and curatorship, 16(3), 257-271.

Wertsch, J.V., 2002. Voices of Collective Remembering. Cambridge: Cambridge University Press. 
Appendix

\section{Organizational perspective}

- Rationale for establishment of the organization

- Aims and objectives of the organization

- Have these changed since the date of establishment and if so in what way?

- How are these stated aims and objectives translated in the daily work of the organization?

- Are there other aims and objectives, beyond the officially stated ones, that form the practice of the organization? How did these come about?

- What is the geographical remit of the organization?

- Explore national, regional and local remit.

- If the organization has a wider remit than popular music, what is its principal focus?

- How does popular music fit in?

- How is this structured?

- Aims and objectives of interviewee's position

- Have these changed since the date of establishment and if so in what way?

- Are there other aims and objectives, beyond the officially stated ones, that form the practice of the organization? How did these come about?

- How is the organization funded? Explore public and private funding.

\section{Content of collection}

- What material does your collection cover relating to popular music?

○ Type of material

Catalogue sections: by genre, by period, by place?

- Are there sections that are more comprehensive than others? Are there any gaps in the material? Please explain why this may be the case.

- How does the organization collect its material?

○ Sources; donations; acquisitions

- In house research

- How is the collection catalogued and stored?

○ Digital collection; record storage...

- Public access

- How is your catalogue used?

○ Internally/externally? 
○ Please provide some examples.

\section{Heritage and identity}

- What is your understanding of the term 'cultural heritage'? [Do you regard it as a meaningful/useful term in relation to your organization?]

- In what ways does the work of your organization inform ideas of local or national heritage in (country)?

- In what ways does the work of your organization inform ideas of local/regional or national identity in (country)?

- What is the organization's relationship to other heritage institutions?

- To what extent does your organization consider popular music as integral to the cultural heritage of (country)?

- Specific activities in place to support this?

$\circ$ Relation to other cultural heritage institutions?

- $\quad$ How does you organization address issues of inclusivity [or inclusiveness] and diversity in popular music history in [your country]?

\section{External links}

- Does the organization collaborate with other organizations?

If yes, in what fields of activity?

- Explore links with other cultural organizations or with the music industry

- Explore links across space, including international links.

\section{$\underline{\text { Audiences }}$}

- What are the organization's audiences?

- How do audiences approach the organization and for what reasons?

- Are there generational differences in how audiences relate to your organization?

- In what ways does your organization promote its visibility to external audiences?

- Activities?

O Own communication strategy?

$\circ$ Does your organization target different audiences differently?

Policy

- Have there been specific policies that have impacted positively or negatively on your organization's work?

- European, national, regional, local 
$\circ$ Active role in policy development and framing?

\section{Personal perspective}

- What was your first record?

- What are your musical preferences and tastes?

- How would you describe your own personal connection to Dutch popular music?

- Explore specific memories of events, bands, venues

- Explore personal practices connected to popular music (amateur/professional musical practice; listening; attendance to musical performances; participation in discussions on popular music; policy engagement)

- What are your views on the visibility and coverage of Dutch popular music in

- Publications; Documentaries and TV series; Radio; Photography; other?

- Other cultural heritage institutions (historical museums, heritage sites)

- Are there sub-genres/periods/localities that get more/less attention? Should that be different in your view?

- What are your views on the way Dutch popular music is represented in the abovementioned outlets?

- Is there a dominant account of its history and development?

$\circ$ How is this shaped and by whom?

$\circ$ Has there been a change in time?

- What are your views on Dutch popular music since the late 1950s?

- Explore views on its history and development

- Views on its position in relation to other genres/popular music from other countries

- How does the development of popular music in the (country) compare to other countries you are familiar with?

- In your view, does popular music heritage contribute to shaping a sense of identity in the (country)?

- National, regional and local level

- If yes, in what way does this occur? 